\title{
Improvement of Bone and Dental Phenotype of Murine Hypophosphatasia Mediated by a Single Injection of Lentiviral Gene Therapy
}

\author{
Seiko Yamamoto-Nemoto ${ }^{1}$, Kei Ogawa', Eri Yokoi ${ }^{1}$, Kanako Sawamoto ${ }^{1}$, Akane Yamaguchi', \\ Elif Bahar Tuna'2, Takehiko Shimizu' ${ }^{1}$ \\ ${ }^{1}$ Department of Pediatric Dentistry, Nihon University School of Dentistry at Matsudo, Matsudo, Japan \\ ${ }^{2}$ Department of Pediatric Dentistry, Faculty of Dentistry, Istanbul University, Istanbul, Turkey \\ Email: yamamoto.seiko@nihon-u.ac.jp
}

How to cite this paper: Yamamoto-Nemoto, S., Ogawa, K., Yokoi, E., Sawamoto, K., Yamaguchi, A., Tuna, E.B. and Shimizu, T. (2017) Improvement of Bone and Dental Phenotype of Murine Hypophosphatasia Mediated by a Single Injection of Lentiviral Gene Therapy. Open Journal of Stomatology, 7, 91-103.

http://dx.doi.org/10.4236/ojst.2017.71005

Received: December 6, 2016

Accepted: January 15, 2017

Published: January 18, 2017

Copyright $\odot 2017$ by authors and Scientific Research Publishing Inc. This work is licensed under the Creative Commons Attribution International License (CC BY 4.0).

http://creativecommons.org/licenses/by/4.0/

\begin{abstract}
Background: Alkaline phosphatase has 4 isozymes, tissue non-specific alkaline phosphatase (TNAP), placental alkaline phosphatase (PLAP), intestinal alkaline phosphatase and germ-cell alkaline phosphatase. Hypophosphatasia (HPP) is an inherited skeletal disease caused by mutations of the gene encoding TNAP. Although TNAP is expressed in various tissues, the primary HPP symptoms appear in bones and teeth. The clinical severity of HPP varies widely from the most severe (perinatal, infantile and childhood) to the mildest forms (adult, and odonto-hypophosphatasia). We reported that gene therapy using a single injection of lentiviral vector expressing bone-targeted TNAP (TNAP- $\mathrm{D}_{10}$ ) is effective in preventing all the skeletal of HPP in TNAP knockout $\left(\mathrm{AlpF}^{--}\right)$mice as the model of infantile HPP. Objective: In this study we focus on evaluating the efficacy of treatment with gene therapy on the bone and teeth using TNAP- $\mathrm{D}_{10}$ and also we investigate the feasibility of gene therapy using bone-targeted PLAP (PLAP- $\mathrm{D}_{10}$ ). Methods and Findings: We used $A l p I^{--}$mice that develop skeletal disease at postnatal days 6-8 mimicking the infantile form of human HPP. We injected $100 \mu \mathrm{l}$ of lentiviral vectors harboring TNALP-D ${ }_{10}\left(5.0 \times 10^{7} \mathrm{TU}\right)$ or PLAP-D P $_{10}\left(5.0 \times 10^{7} \mathrm{TU}\right)$ to 1-day-old $A l p F^{--}$mice via the jugular vein. We performed histological analysis and micro-CT evaluation on bone and mandible of $\mathrm{AlpH}^{--}$mice. The alveolar bone, enamel and dentin defects were corrected on treated $A l p F^{--}$mice by this treatment. Additionally the long bone growth rates (LGR) of long bones were encouraged on treated $\mathrm{AlpF}^{--}$mice compared with untreated mice. Conclusions: These results indicate that the bone-targeted TNAP treatment mediated by lentivirus can correct not only the bone disorder but also the dental symptoms in $\mathrm{Alpl}^{-1}$. This study also shows that PLAP- $\mathrm{D}_{10}$ can potentially be used to correct HPP disease.
\end{abstract}




\section{Keywords}

Hypophosphatasia, Odonto-HPP, Tissue Non-Specific Alkaline Phosphatase

\section{Introduction}

The human alkaline phosphatase family is composed of 4 isozymes, tissue nonspecific alkaline phosphatase (TNAP), placental alkaline phosphatase (PLAP), intestinal alkaline phosphatase and germ-cell alkaline phosphatase. Hypophosphatasia (HPP) is an inherited skeletal disease caused by mutations in the alkaline phosphatasegene ( $A L P L)$ encoding TNAP. Mutations in ALPL result in deficient activity of TNAP leading to skeletal and dental disease often causing death in the first year of life. Indeed, although TNAP is expressed in a variety of tissues, the HPP symptoms appear first in bones and teeth [1]. The main physiological substrate of TNAP responsible for the skeletal phenotype is the mineralization inhibitor inorganic pyrophosphate ( $\mathrm{PPi})$. The hypomineralization is caused by local accumulation of PPi inhibiting hydroxyapatite crystal growth [2]. The clinical severity of HPP varies widely. Listed from the most severe to the mildest forms HPP is classified as: perinatal, infantile, childhood, adult, and odonto-hypophosphatasia. The characteristic dental symptoms are the premature primary teeth defluxion, alveolar bone and enlarged dentalpulp chamber and teeth substances defects [3].

HPP prevalence was reported in 1957 to be around 1:100,000 live births for the severe forms [4]. Recently, estimates of 1:300,000 have been reported for Europe [1]. Although the prevalence has not been established in Japan, it has been reported that c.1559delT in ALPL is the most frequent mutation, characteristic mutation of Japanese, and the heterozygote carrier is 1 in 480 Japanese [5]. There is no established medical treatment of HPP.

In 2008, reports indicated that enzyme replacement therapy (ERT) using daily injections of bone-targeted TNAP $\left(\right.$ TNAP- $D_{10}$ ) is effective in preventing all the skeletal and dental manifestations of HPP in TNAP knockout $\left(\right.$ Alp $\left.^{-1}\right)$ mice [6] [7] [8]. Recently ERT has been approved for pediatric-onset HPP in Japan [9]. However, the treatment entails daily subcutaneous injections and the treatment is expensive. Gene therapy offers potential advances on these issues. Several studies of gene therapy using viral vectors for murine HPP have been performed to-date [11] [12] [13] [14]. Single injections of either a lentivitral vector or an adeno-associated viral (AAV) vector during the neonatal period corrected the bone phenotype and prolonged the life of $\mathrm{AlpI}^{--}$mice [10] [11] [12]. Subsequently in utero treatments by AAV vector and bone marrow cells (BMC) transplantation transduced with lentiviral vector treatment for murine HPP were investigated [13] [14]. These treatments using the bone targeted TNAP- $D_{10}$ also proved effective for bone phenotype, especially the BMC transplantation improved teeth symptoms [15].

In this study, we used a single injection of a viral vector and we focused on 
correction of the phenotype in the mandible, the alveolar bone and teeth in $\mathrm{AlpF}^{-1}$ mice using micro-CT and histological analysis. Furthermore we conducted bone histomorphometry to evaluate the therapeutic efficacy for long bones with single injection of lentiviral gene therapy. We also investigate the feasibility of gene therapy using bone-targeted placental alkaline phosphatase $\left(\mathrm{PLAP}-\mathrm{D}_{10}\right)$, one of the isozymes of alkaline phosphatase.

\section{Methods}

\subsection{Plasmid Construction}

Polymerase chain reaction (PCR) was used as described previously [10] to produce TNAP- $\mathrm{D}_{10}$ cDNA encoding TNAP lacking the glycosylphosphatidylinositol anchor and 10 repeated aspartic acid (Asp). PLAP- $D_{10}$ cDNA coding for PLAP without the GPI anchor containing 10 Asp was created by PCR using primers PLAP-D10-f (5'-TTT CAA TTG GCC ACC ATG CCC AGA ATT CCT GCC TCG CCA CTG TCC-3') and PLAP-D ${ }_{10}$-r (5'-TTT GCG GCC GCT CAG TCG TCA TCATCATCA TCG TCG TCA TCG TCC CGC AGG GTG GTG CCG GCG GGG GGC GCC AG-3') with pcDNA3 PLAP cDNA plasmid (NM_ $001632,2.987 \mathrm{kbs}$ ) as the template. The PCR conditions were $96^{\circ} \mathrm{C}$ were for 10 min, followed by $30 \mathrm{cycles}$ of $94^{\circ} \mathrm{C}$ for $30 \mathrm{sec}, 61^{\circ} \mathrm{C}$ for $1 \mathrm{~min}, 72^{\circ} \mathrm{C}$ for $2 \mathrm{~min}$, and $72^{\circ} \mathrm{C}$ for $10 \mathrm{~min}$. The PCR product was digested with Mfel and NotI and inserted into the constructing plasmid, equally applicable to TNAP- $\mathrm{D}_{10}$ as described previously [10]. The sequencing of each plasmid was performed to confirm the orientation (Figure 1).

\subsection{Lentiviral Vector Preparation}

Lentivital vector was prepared by transfection in $293 \mathrm{~T}$ cells, as described previously [10].

The harvested viral containing medium was cleared by low speed centrifugation $\left(500 \mathrm{~g}\right.$ for $10 \mathrm{~min}$ at $4^{\circ} \mathrm{C}$ ), then filtrated through $0.45 \mu \mathrm{m}$ pore size filter. The filtrated medium was concentrated by ultracentrifuge with a $20 \%(\mathrm{w} / \mathrm{v})$

(a)

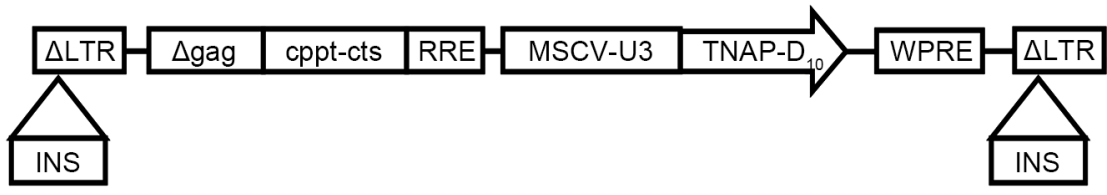

(b)

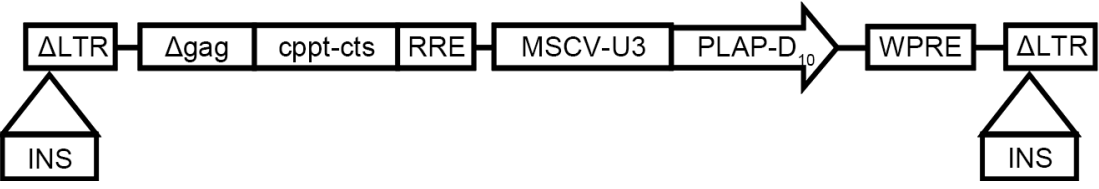

Figure 1. Vector construction. (a) Schematic diagram of lentiviral vector of TNAP-D ${ }_{10}$. (b) Schematic diagram of lentiviral vector of PLAP-D $D_{10}$. LTR = long terminal repeat; MSCVU3 = U3 region of the LTR promoter of murine stem cell virus; WPRE $=$ woodchuck hepatitis virus posttranscriptional regulatory element; INS $=$ chicken $\beta$-globin hypersensitivity site 4 insulator; cppt-cts = central polypurine tract-central termination sequence; $\mathrm{RRE}=$ reverse responsive element. 
sucrose underlay for purification. The titrations of the vector were performed by transfection in HeLa cells. The titer was indicated as transducing units per milliliter $(\mathrm{TU} / \mathrm{mL})$.

\subsection{Animal Procedures and Experiments}

All animal experiments and animal care procedure were conducted with approval of the Animal Usage Committee of the Sanford Burnham Medical Research Institute, La Jolla, CA, USA. Alpl null mice were created as described previously [16]. The $\mathrm{AlpH}^{-1-}$ mice develop skeletal disease at day 6-8 and usually die of their disease at postnatal day 20. $A l \mathrm{PI}^{\mathrm{H}^{++}}$(WT) mice and $A l p \mathrm{~F}^{--}$mice were obtained by breeding $A l \mathrm{PI}^{\mathrm{H}-}$ heterozygous mice mixed $129 \mathrm{~J} \times \mathrm{C} 57 \mathrm{Bl} / 6 \mathrm{~J}$ background. The breeding pairs were fed CMF laboratory feed added 325 ppm pyridoxine/10 kg (Oriental Yeast Co., Ltd., Tokyo, Japan). Lentiviral vector $(5.0 \times$ $10^{7} \mathrm{TU}$ ) was injected into jugular vein of 1day old mice [10]. Mice were injected with alizarin red $20 \mathrm{mg} / \mathrm{kg}$ (Sigma-Aldrich, St. Louis, MO, USA) and calcein 20 $\mathrm{mg} / \mathrm{kg}$ (Sigma-Aldrich, St. Louis, MO, USA) at day 15 and day 20 via subcutaneous injection [17].

\subsection{Bone Histomorphometry}

We followed Kawamoto's film method [18]. The sections cut into $5 \mu \mathrm{m}$ thickness each samples of lower thigh. The sections were stuck on the slide glasses and observed under the fluorescence microscope. The image of alizarin red and calcein were laid over with the software (Image J, U. S. National Institutes of Health, Bethesda, MD, USA) and long bone growth rate (LGR) were calculated as follows: LGR $\mu \mathrm{m} /$ day $=$ the length between alizarin red and calcein/the injected days from day 15 to day 20.

\subsection{H\&E Staining}

The mandibles were fixed in $4 \%$ paraformaldehyde for 24 hours at $4^{\circ} \mathrm{C}$.

The undecalcified frozen sections from mice mandibles were prepared according to Kawamoto's film method [18]. The sections were cut into $5 \mu \mathrm{m}$ thickness each samples.

\subsection{Micro-CT Analysis}

The micro-CT images were obtained using micro-CT (R_mCT2, Rigaku, Tokyo, Japan) and the images were reconstructed in three dimensions using 3-D construction analysis software (TRI/3D-BON, Ratoc System Engineering Co, Tokyo, Japan).

The conditions of micro-CT were $90 \mathrm{kV}, 100 \mu \mathrm{A}$, magnification $\times 6.7$ and measurement time 2 minutes. We measured the bone volumes (BV), bone mineral contents (BMC) and bone mineral density (BMD) of the mandibular bone and tissue mineral contents (TMC) and tissue mineral density (TMD) of the teeth, enamel and dentin as a region $2.0 \mathrm{~mm}$ from the tip of the incisors. The teeth regions analyzed every $30 \mu \mathrm{m} / \mathrm{slice}$ by the software. 


\subsection{Statistical Analysis}

All statistical analysis was performed using SPSS (IBM Corp., Armonk, NY, USA). All data are expressed as the mean $\pm \mathrm{SD}$. ANOVA was used to determine differences between multiple groups, while differences between individual groups were determined by Tukey's test. $p$ values $<0.05$ was considered statistically significant.

\section{Results}

\subsection{Comparison of the Long Bone Growth Rate with Bone Histmorphometry}

Bone histomorphometry were performed at postnatal day 21 . The first labels of alizarin rad were shown in red and the second labels of calcein were shown in green, the merged areas are shown in yellow (Figure 2).

WT mice had spacious calcified calcein stained area (Figure 2(a)). All WT mice showed similar patterns of trabecular bones and cortical bones. Instead, the untreated $\mathrm{Alpl}^{--}$mice had extensive red area whereat primitively calcified (Figure 2(b)) and the yellow areas were only sporadically observed. Moreover the width of epiphysis were wide in the untreated $A l \mathrm{PF}^{-1}$ all mice. Meanwhile both the TNAP- $\mathrm{D}_{10}$ and PLAP- $\mathrm{D}_{10}$ treated $A l p F^{-1}$ mice tend to be close to WT in appearance (Figure 2(c), Figure 2(d)). However width of epiphysis with treated mice were still wider in comparison with WT mice.

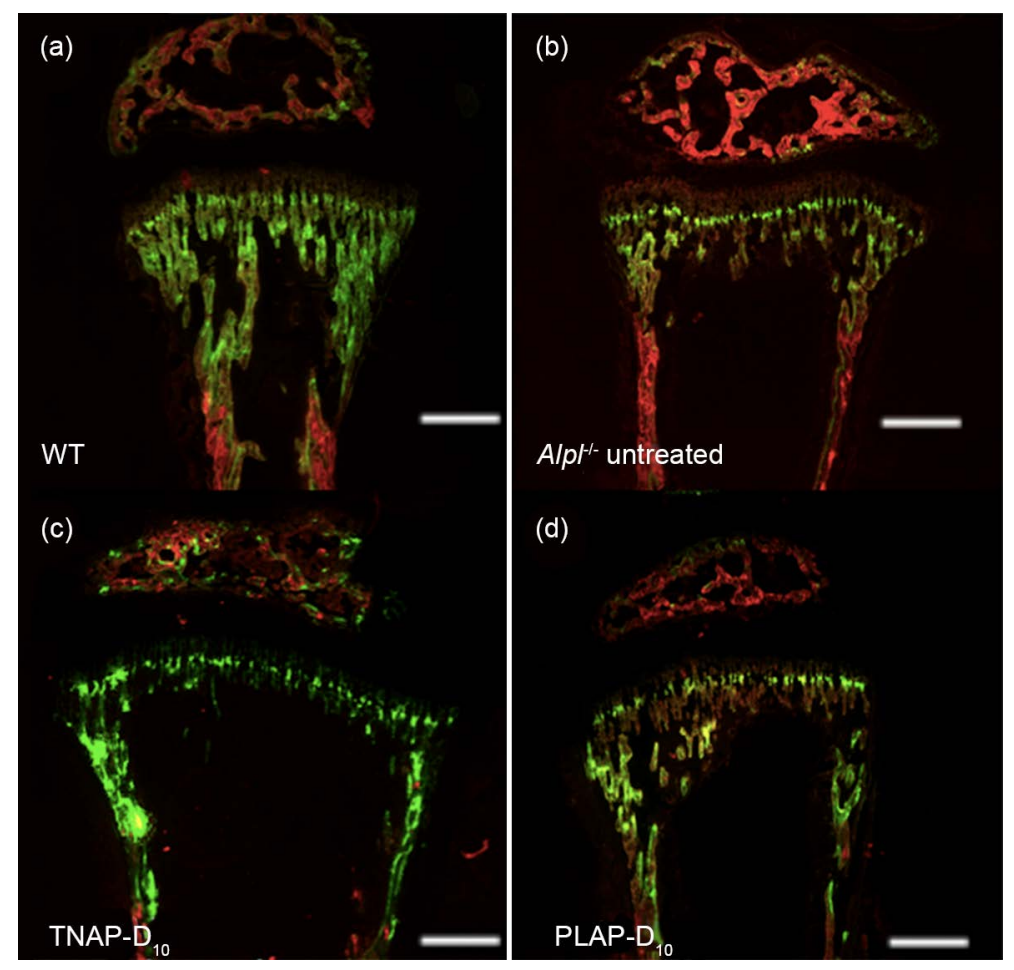

Figure 2. Investigation of bone growth by bone histomorphometry. Alizarin red were injected to mice on day 15 after birth. Calcein was injected on day 20. The mice were sacrificed on $24 \mathrm{hr}$ after calcein injection. LGR indicated the distance between alizarin red and calcein fluorescence labels of bone (showed by while arrow) divided by 5 days. 
Next we investigated whether the LGR of $\mathrm{AlpH}^{--}$mice improved by single lentivial injection for the early stage, from 14 days to day 19 after injection. The results of LGR indicated no significantly difference between WT and TNAP-D ${ }_{10}$ treated $\mathrm{AlpI}^{--}$mice and untreated $\mathrm{AlpI^{-- }}$ mice and PLAP-D ${ }_{10}$ treated. On the, LGR significantly was improved in the TNAP-D $\mathrm{D}_{10}$ treated mice compared to $A l p I^{-1-}$ mice (Figure 3).

\subsection{Histological Analysis of Mandibles with H\&E Staining}

The enamel and dentin defects were observed with incisors of untreated $\mathrm{AlpI}^{-1-}$ mice on the sections of H\&E staining at 21 days of age in agreement with earlier reports [8], while incisors of WT mice showed uniformed and thickly enamel and dentin layers (Figure 4(a), Figure 4(b)).

The thick enamel and dentin were also present in the TNAP- $\mathrm{D}_{10}$ treated $\mathrm{AlpI}^{\mathrm{H}^{-}}$mice 20 days after injection (Figure $4(\mathrm{c})$ ). The PLAP-D ${ }_{10}$ treated mice had the rippling enamel layer and thick dentin layer with the incisors (Figure $4(\mathrm{~d})$ ). The ameloblastic layers of TNAP-D ${ }_{10}$ treated $A l p I^{--}$mice were height wiseuniforme and comparable to WT mice, whereas the $\mathrm{AlpI}^{-/}$mice showed an uneven short ameloblasts layer (Figure 4(a), Figure 4(b), Figure 4(c)).

\subsection{Micro-CT Analysis of Alveolar Bones and Teeth}

To confirm the effect of lentiviral single injection therapy for not only long bones but also mandibles, we performed the comparison of the interproximal alveolar bone area volume, BMD and BMC for each groups. The results showed significantly difference between WT, TNAP-D ${ }_{10}$ treated and PLAP-D 10 treated and untreated $\mathrm{AlpI}^{--}$mice. As for both lentiviral treated mice, these components

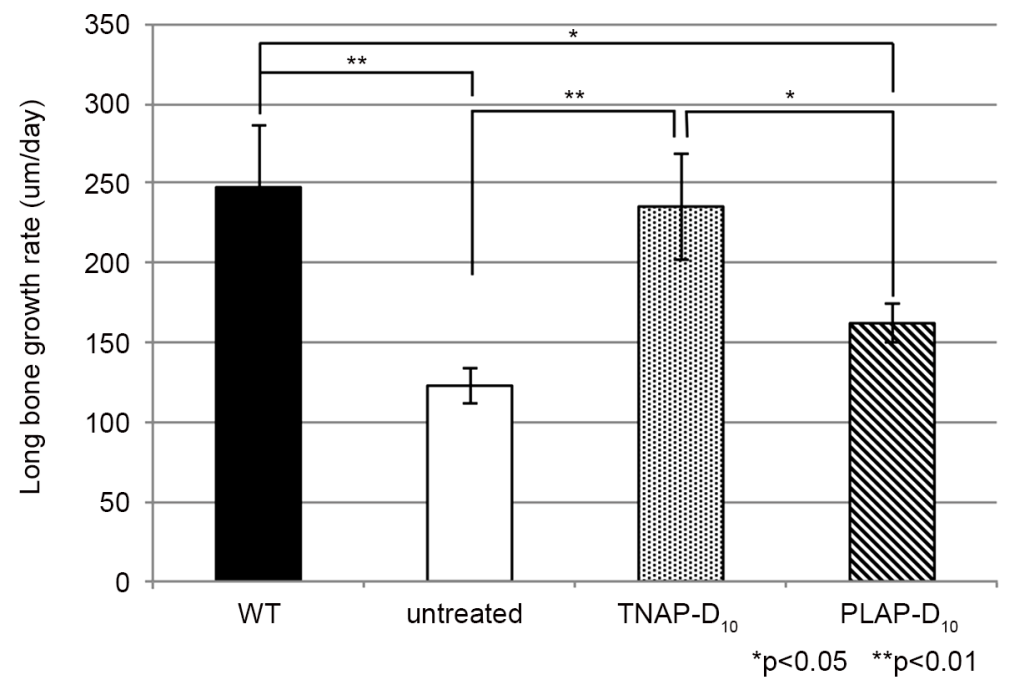

Figure 3. Epiphysial growth rate of tibia is shown on this graph as LGR. The LGR of untreated $\mathrm{AlpH}^{{ }^{-1}}$ mice and PLAP-D $\mathrm{D}_{10}$ treated mice were significantly lower than WT. PLAP$\mathrm{D}_{10}$ treated $\mathrm{AlpH}^{--}$mice showed higher growth rate more than untreated $\mathrm{AlpH}^{-1}$ mice. Whereas TNAP-D $\mathrm{D}_{10}$ treated $A l p I^{-1}$ mice were close to WT value and there is no significantly difference. WT $(\mathrm{n}=6)$, TNAP- $\mathrm{D}_{10}$ treated $(\mathrm{n}=5)$, PALP- $\mathrm{D}_{10}(\mathrm{n}=5)$ and untreated AlpF $^{--}(\mathrm{n}=3)$. The magnification was $\times 40$, the bars were shown $200 \mu \mathrm{m}$. 

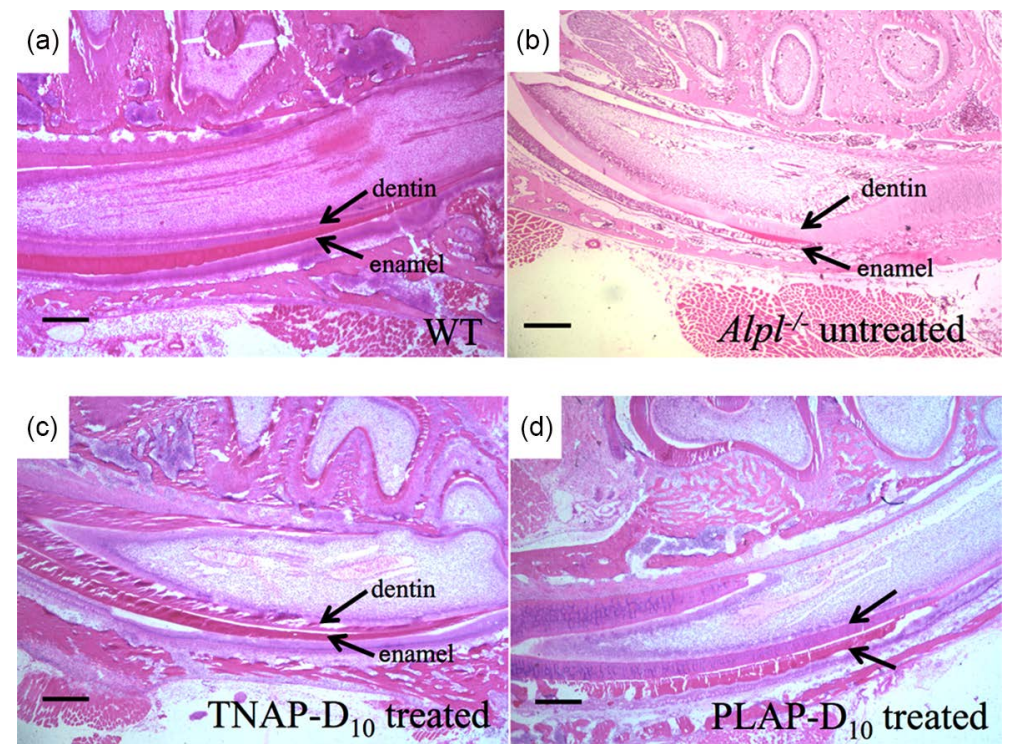

Figure 4. H\&E staining of mandibles. Histological analysis of mouse mandibles with single injection gene therapy treated $\mathrm{AlpH}^{-1-}$ mice. The magnification was $\times 40$, the bars were shown $200 \mu \mathrm{m}$. (a) Uniformed thicker enamel and dentin layer and ameloblastic layer were shown in WT mice; (b) A thinner uneven enamel and dentin layer were shown in untreated $\mathrm{AlpI}^{-/}$mice. Loss of organization of ameloblasts layer was shown. (c), (d) TNAP-D ${ }_{10}$ treated $A l p I^{-/}$mice and PLAP-D ${ }_{10}$ Treated $A l p F^{-/}$mice had a thicker enamel layer than the untreated $A l p I^{-1}$ mice. TNAP-D 10 treated $A l p I^{-1-}$ mice were uniformed and corrected undulate layer compared with PLAP-D 10 treated.

of the micro-CT examination were similar to WT value, no significant difference among the WT and the treated $\mathrm{AlpH}^{-1-}$ mice (Figure 5).

To evaluate the effectiveness of gene therapy for teeth, we investigated the volume, mineral contains and mineral densities of incisor tips with every 30 slices by micro-CT. About $2.0 \mathrm{~mm}$ tip of the incisor consist of enamel and dentin regions (Figure 6(a)-(d)), the tips of incisor of TMD and tissue mineral content TMC with WT and TNAP- $\mathrm{D}_{10}$ treated $A l p \mathrm{I}^{-1}$ mice were significantly higher than that of $A l p F^{-\alpha}$ mice PLAP-D 10 treated (Figure 6(e), Figure 6(f)). Untreated $\mathrm{AlpI}^{-1}$ was not shown because of the less number of the sample for the statistical analysis.

\section{Discussion}

Previously we showed that a single injection of either a lentiviral vector or an adeno-associated viral vector harboring TNAP- $\mathrm{D}_{10}$ was equally effective in preventing all the manifestations of HPP [10] [11]. We showed prolongation of life more than 150 days and improvement of the skeletal mineralization status in treated mice. Recently, correction of the tooth defect in the HPP mouse model treated by ERT [8] [19] and lentiviral transduced BMC using TNAP- $D_{10}$ were reported [15]. The above reports investigated long-term effects of the treatment for more than a month. These reports examined the long bones and teeth and indicated the correction of bone and dental phenotypes.

The current study investigated the effect of single lentiviral injection gene 

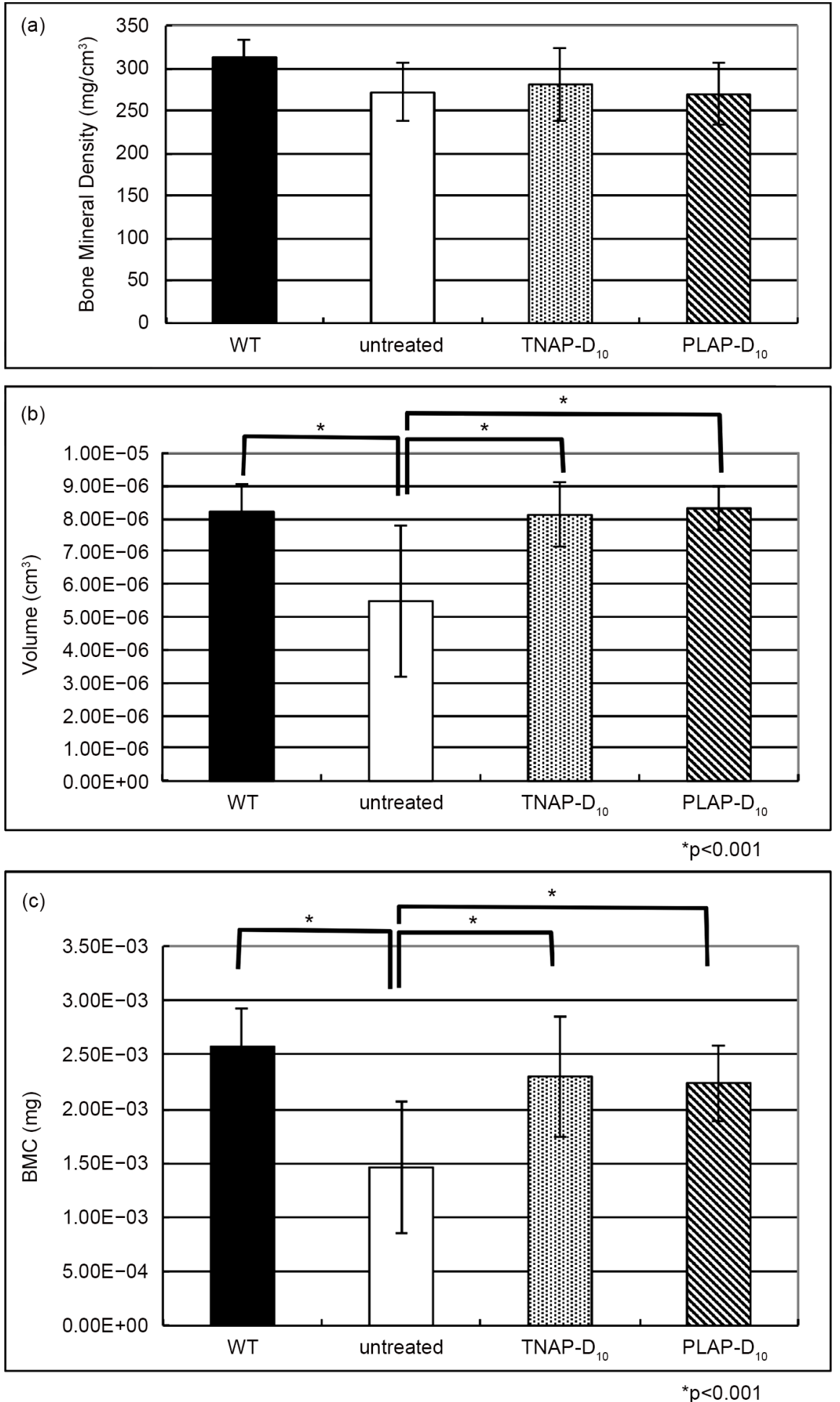

Figure 5. Micro-CT analysis of alveolar bone. (a) The values of bone mineral density of

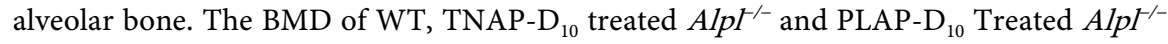
mice were no significantly difference compared with untreated $A l p I^{-1-}$ mouse; (b) While the bone volume of untreated mouse was significant lower than other 3 groups $\left({ }^{*} p<\right.$ 0.001); (c) There were no significant differences between WT, TNAP- $\mathrm{D}_{10}$ treated $A 1 \mathrm{pl}^{-1}$ and PLAP-D ${ }_{10}$ Treated $A l \mathrm{PH}^{-/}$mice with BMC. The BMC of untreated $A l p I^{-1-}$ was significantly lower than the treated $\operatorname{AlpI}^{H^{--}}\left({ }^{*} p<0.001\right)$. WT $(\mathrm{n}=6)$, TNAP-D $\mathrm{D}_{10}$ treated $(\mathrm{n}=5)$, PALP-D $10(\mathrm{n}=5)$ and untreated $\operatorname{AlpI}^{--}(\mathrm{n}=1)$. 

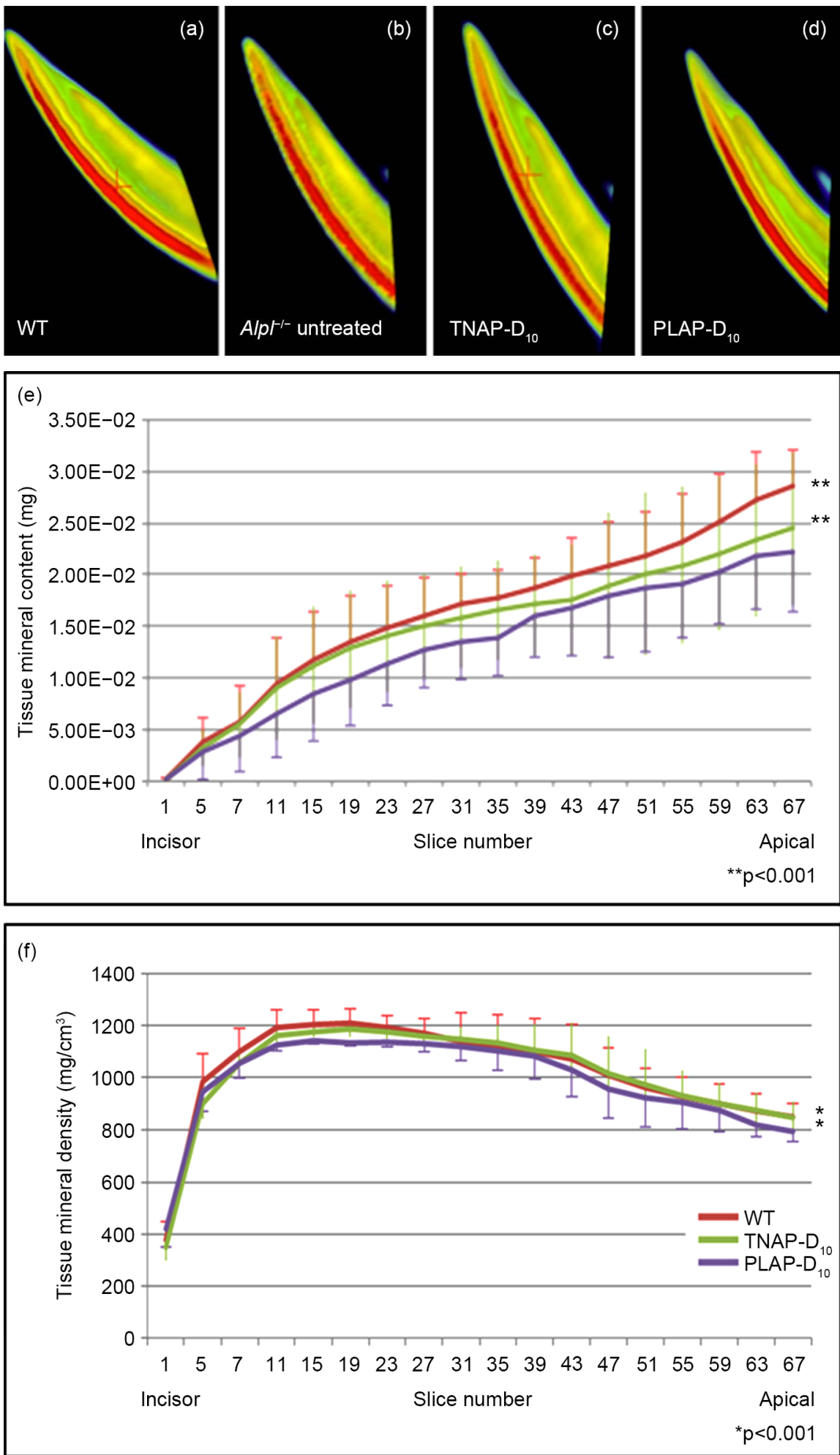

Figure 6. Micro-CT analysis of enamel and dentin regions. (a)-(d) The images of enamel and dentin regions with mandibles. We examined TMC and TMD of the $2.0 \mathrm{~mm}$ tip of mandibles as teeth regions; (e), (f) The graphs showed that the plots of TMC and TMD value every $30 \mu \mathrm{m}$ slice for $2.0 \mathrm{~mm}$ from incisor to apical. WT and TNAP-D $\mathrm{D}_{10}$ treated AlpI $^{--}$mice were significantly higher than PLAP-D ${ }_{10}$ treated with TMC and TMD of micro-CT analysis. WT $(\mathrm{n}=6)$, TNAP- $\mathrm{D}_{10}$ treated $(\mathrm{n}=5)$, PALP-D $_{10}(\mathrm{n}=5)$ and untreated $\operatorname{AlpI}^{{ }^{--}}(\mathrm{n}=1)$. 


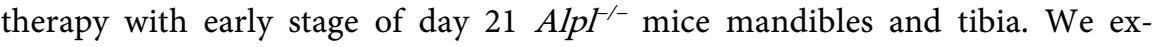
amined the $A l \mathrm{PH}^{--}$mice on 20 days after the administration of lentiviral vector. Bone histomorphometry revealed that the LGR improved on day 21 of $\mathrm{AlpF}^{-1}$ mice by the TNAP- $\mathrm{D}_{10}$ expressing vector injection (Figure 3 ). The injected lentiviral vector led to expression of TNAP-10 on the bone surface, as reported previously [10]. Thus, this result indicated that secreted TNAP- $D_{10}$ promotes bone growth at this early stage and increased the amount of bone formation. The study confirmed the bone phenotype correction of lentiviral single injection gene therapy by biological marker in a dynamic way. Furthermore micro-CT analysis indicated that $\mathrm{BMC}$ and $\mathrm{BMD}$ of the alveolar bone were improved with TNAP-D ${ }_{10}$ treated $A l p F^{1-}$ mice (Figure 5(a), Figure 5(c)). Mandible bone was different in the way of formation from a long bone. Especially alveolar bone has the distinctive character, comprised alveolar process, trabecular bone and alveolar plate [20]. Okawa et al. reported that BMC treatment of $\mathrm{AlpH}^{-1-}$ mice were effective for the cementum and the alveolar bone around the first molar [15]. As to the single injection gene therapy also showed that the alveolar bone, the trabecular bone and alveolar process, correction in this study.

Enamel disorders are caused by ameloblasts dysfunction during their maturation stage [21]. TNAP expression exists in all ameloblasts entering the maturation stage of mouse incisor by postnatal day 10 [8]. A mouse incisor shows all the processes of enamel organ formation during tooth eruption. Moreover mice do not have the succedaneous teeth. Thus, animal studies do not exactly correspond to the biology of human teeth. However, we considered that the incisors show a comparable structure and cellular events, and we used the incisors of $A l p{F^{-1}}^{-}$mice in this study. Yadav et al. showed that low dose ERT did not correct enamel formation in $A l p I^{--}$mice while high dose ERT did [8]. In this study, untreated $A l p F^{--}$mice showed the absence of enamel and dentin layer with $\mathrm{H} \& \mathrm{E}$ staining (Figure 4). Conversely the TNAP-D ${ }_{10}$ treated $\mathrm{AlpF}^{-\alpha}$ mice dental phenotypes, enamel and dentin defects, were corrected (Figure 4(a), Figure 4(b), Figure 4(c)). Also the morphology of treated ameloblasts improved and became comparable to that of WT mice. Additionally, significant differences, were found between TNAP- $\mathrm{D}_{10}$ treated and PLAP- $\mathrm{D}_{10}$ treated $A l p \mathrm{~F}^{--}$mice in the TMD and TMC on the enamel and dentin regions. This result indicated that the alveolar bone and dental phenotype of TNAP- $\mathrm{D}_{10}$ were corrected (Figure 6(e), Figure 6(f) ) more than PLAP- $\mathrm{D}_{10}$ by this gene therapy. Thus the results indicate that the $\mathrm{AlpF}^{-1}$ dental manifestations, especially enamel and dentin defects, improved with TNAP supplied by lentiviral gene therapy.

Several ERT studies using of mineral-targeted TNAP has been performed in HPP patients [9]. PLAP has not yet been used for ERT. However PLAP is physiologically active toward substrates of TNAP including PPi [22] [23]. KifferMoreira et al. examined the ability of flag-tagged PLAP compared to flag-tagged TNAP- $\mathrm{D}_{10}$, and flag-tagged PLAP showed lower catalytic efficiency than that of TNAP-D ${ }_{10}$ [24]. Here we showed that PLAP-D ${ }_{10}$ treated Alp ${ }^{-\alpha}$ mice did not show a significantly phenotypically correction of $\mathrm{AlpF}^{-1}$ mice except the mi- 
cro-CT analysis of alveolar bone. As to $\mathrm{H} \& \mathrm{E}$ staining, enamel and dentin defects were corrected on PLAP-D ${ }_{10}$ treated $A l \mathrm{PI}^{-1-}$ mice less than that of TNAP-D 10 treated $A l \mathrm{pI}^{--}$mice. Thus these results indicated that PLAP-D ${ }_{10}$ slightly improved the $\mathrm{AlpI}^{-1-}$ mice disorders on bone and teeth. Although, clearly less efficient that TNAP- $\mathrm{D}_{10}$, gene therapy using PLAP- $\mathrm{D}_{10}$ may have the potential for use in the treatment of HPP.

\section{Conclusion}

In conclusion these results indicate that bone-targeted TNAP treatment mediated by lentivirus can correct not only bone discloser but also dental symptoms in this mouse model of infantile HPP on day 21. This study also shows that PLAP-D ${ }_{10}$ may possibly be used to correct some of the symptoms of HPP.

\section{Acknowledgements}

This research was supported by JSPS KAKENHI Grant Number JP25862035 and JP16K20658 and a grant from the Research Institute of Oral Science, Nihon University School of Dentistry at Matsudo.

\section{Conflict of Interest}

All contributing authors declare no conflicts of interest.

\section{References}

[1] Whyte, M.P. (2016) Hypophosphatasia-Aetiology, Nosology, Pasthogenesis, Diagnosis and Treatment. Nature Reviews Endocrinology, 12, 233-246.

https://doi.org/10.1038/nrendo.2016.14

[2] Orimo, H. (2010) The Mechanism of Mineralization and the Role of Alkaline Phosphatase in Health and Disease. Journal of Nippon Medical School, 77, 4-12. https://doi.org/10.1272/jnms.77.4

[3] Reibel, A., Manière, M.C., Clauss, F., Droz, D., Alembik, Y., Mornet, E. and BlochZupan, A. (2009) Orodental Phenotype and Genotype Findings in All Subtypes of Hypophosphatasia. Orphanet Journal of Rare Diseases, 4, 6. https://doi.org/10.1186/1750-1172-4-6

[4] Whyte, M.P., Zhang, F., Wenkert, D., McAlister, W.H., Mack, K.E., Benigno, M.C., Coburn, S.P., Wagy, S., Griffin, D.M., Ericson, K.L. and Mumm, S. (2015) Hypophosphatasia-Validation and Expansion of the Clinical Nosology for Children from 25 Years Experience with 173 Pediatric Patients. Bone, 75, 229-239. https://doi.org/10.1016/j.bone.2015.02.022

[5] Watanabe, A., Karasugi, T., Sawai, H., Than Naing, B., Ikegawa, S., Orimo, H. and Shimada, T. (2011) Prevalence of c.1559delT in ALPL, a Common Mutation Resulting in the Perinatal (Lethal) form of Hypophosphatasia in Japanese and Effects of the Mutation on Heterozygous Carriers. Journal of Human Genetics, 56, 166168. https://doi.org/10.1038/jhg.2010.161

[6] Millán, J.L. Narisawa, S., Lemire, I., Loisel, T.P., Boileau, G., Leonard, P., Gramatikova, S., Terkeltaub, R., Pleshko, C.N., McKee, M.D., Crine, P. and Whyte, M.P. (2008) Enzyme Replacement Therapy for Murine Hypophosphatasia. Journal of Bone and Mineral Research, 23, 777-787. https://doi.org/10.1359/jbmr.071213

[7] McKee, M.D., Nakano, Y., Masica, D.L., Gray, J.J., Lemire, I., Heft, R., Whyte, M.P., 
Crine, P. and Millán, J.L. (2011) Enzyme Replacement Prevents Dental Defects in a Mouse Model of Hypophosphatasia. Journal of Dental Research, 90, 470-476. https://doi.org/10.1177/0022034510393517

[8] Yadav, M.C., Lemire, I., Leonard, P., Boileu, G., Blond, L., Beliveau, M., Cory, E., Sah, R.L., Whyte, M.P., Crine, P. and Millán, J.L. (2011) Dose Response of BoneTargeted Enzyme Replacement of Murine Hypophosphatasia. Bone, 49, 250-256. https://doi.org/10.1016/j.bone.2011.03.770

[9] Okazaki, Y., Kitajima, H., Mochizuki, N., Kitaoka, T., Michigami, T. and Ozono, K. (2016) Lethal Hypophosphatasia Successfully Treated with Enzyme Replacement from Day 1 after Birth. European Journal of Pediatrics, 175, 433-437. https://doi.org/10.1007/s00431-015-2641-2

[10] Yamamoto, S., Orimo, H., Matsumoto, T., Iijima, O., Narisawa, S., Maeda, T., Millán, J.L. and Shimada, T. (2011) Prolonged Survival and Phenotypic Correction of Akp2 $\left(/^{-}\right)$Hypophosphatasia Mice by Lentiviral Gene Therapy. Journal of Bone and Mineral Research, 26, 135-142. https://doi.org/10.1002/jbmr.201

[11] Matsumoto, T., Miyake, K., Yamamoto, S., Orimo, H., Miyake, N., Odagaki, Y. Adachi, K., Iijima, O., Narisawa, S., Millán, J.L., Fukunaga, Y. and Shimada, T. (2011) Rescue of Severe Infantile Hypophosphatasia Mice by AAV-Mediated Sustained Expression of Soluble Alkaline Phosphatase. Human Gene Therapy, 22, 1355-1364. https://doi.org/10.1089/hum.2010.210

[12] Nakamura-Takahashi, A., Miyake, K., Watanabe, A., Hirai., Y., Iijima, O., Miyake, N., Adachi, K., Nitahara-Kasahara, Y., Kinoshita, H., Noguch, T., Abe, S., Narisawa, S., Millán, J.L., Shimada, T. and Okada, T. (2016) Treatment of Hypophospatasia by Muscle-Directed Expression of Bone-Targeted Alkaline Phosphatase via Self-Complementary AAV8 Vector. Molecular Therapy_Methods \& Clinical Development, 3, Article 15059. https://doi.org/10.1038/mtm.2015.59

[13] Sugano, H., Matsumoto, T., Miyake, K., Watanabe, A., Iijima, O., Migita, M., Narisawa, S., Millán, J.L., Fukunaga, Y. and Shimada, T. (2012) Successful Gene Therapy in Utero for Lethal Murine Hypophosphatasia. Human Gene Therapy, 23, 399-406. https://doi.org/10.1089/hum.2011.148

[14] Iijima, O., Miyake, K., Watanabe, A., Miyake, N., Igarashi T., Kanokoda, C., Nakamura-Takahashi, A., Kinoshita, H., Noguch, T., Abe, S., Narisawa, S., Millán, J.L., Okada, T. and Shimada, T. (2015) Prevention of Lethal Murine Hypophosphatasia by Neonatal Ex Vivo Gene Therapy Using Lentivirally Transduced Bone Marrow Cells. Human Gene Therapy, 26, 801-812. https://doi.org/10.1089/hum.2015.078

[15] Okawa, R., Iijima, O., Kishino, M., Okawa, H., Toyosawa, S., Sugano-Tajima, H., Shimada, T., Okada, T., Ozono, K., Ooshima, T. and Nakano, K. (2016) Gene Therapy Improves Dental Manifestations in Hypophospharasia Model Mice. Journal of Periodontal Research. https://doi.org/10.1111/jre.12412

[16] Narisawa, S., Fröhlander, N. and Millán, J.L. (1997) Inactivation of Two Mouse Alkaline Phosphatase Genes and Establishment of a Model of Infantile Hypophosphatasia. Developmental Dynamics, 208, 432-446. https://doi.org/10.1002/(SICI)1097-0177(199703)208:3<432::AID-AJA13>3.0.CO;2-1

[17] Sugimoto, M., Futaki, N., Harada, M. and Kaku, S. (2013) Effects of Combined Treatment with Eldecalcitol and Alendronate on Bone Mass, Mechanical Properties, and Bone Histomorphometry in Ovariectomizedrats: A Comparison with Alfacalcidol and Alendronate. Bone, 52, 181-188. https://doi.org/10.1016/j.bone.2012.09.031

[18] Kawamoto, T. (2003) Use of a New Adhesive Film for the Preparation of MultiPurpose Fresh-Frozen Sections from Hard Tissues, Whole-Animals, Insects and Plants. Archives of Histology and Cytology, 66, 123-143. 
https://doi.org/10.1679/aohc.66.123

[19] Foster, B.L., Nagatomo, K.J., Tso, H.W., NocitiJr, F.H., Narisawa, S., Yadav, M.C., McKee, M.D., Millán, J.L. and Somerman, M.J. (2013) Tooth Root Dentin Mineralization Defects in a Mouse Model of Hypophosphatasia. Journal of Bone and Mineral Research, 28, 271-282. https://doi.org/10.1002/jbmr.1767

[20] Nanci, A. (2013) Ten Cate's Oral Histology. 8th Edition, Elsevier, Amsterdam.

[21] Wise, G.E. and Fan, W. (1989) Changes in the Tartrate-Resistant Acid Phosphatase Cell Population in Dental Follicles and Bony Crypts of Rat Molars during Tooth Eruption. Journal of Dental Research, 68, 150-156. https://doi.org/10.1177/00220345890680021001

[22] Millán, J.L. (2006) Mammalian Alkaline Phosphatases: From Biology to Applications in Medicine and Biotechnology. Wiley-VCH, Weinheim. https://doi.org/10.1002/3527608060

[23] Wennberg, C., Kozlenkov, A., Mauro, S.D., Fröhlander, N., Beckman, L., Hoylaerts, M.F. and Millán, J.L. (2002) Structure, Genomic DNA Typing, and Kinetic Characterization of the D Allozyme of Placental Alkaline Phosphatase (PLAP/ALPP). Human Mutation, 19, 258-267. https://doi.org/10.1002/humu.10052

[24] Kiffer-Moreira, T., Sheen C.R., Gasque, K.C.S., Bolean, M., Ciancaglini, P., Elsas, A.V., Hoylaerts, M.F. and Millán, J.L. (2014) Catalytic Signature of a Heat-Stable, Chimeric Human Alkaline Phosphatase with Therapeutic Potential. PLoS ONE, 9, e89374. https://doi.org/10.1371/journal.pone.0089374

\section{Abbreviations}

TNAP: tissue non-specific alkaline phosphatase

PLAP: placental alkaline phosphatase

HPP: hypophosphatasia

TNAP- $\mathrm{D}_{10}$ : bone-targeted TNAP

Alp ${ }^{-1}$ : TNAP knockout

PLAP- $\mathrm{D}_{10}$ : bone-targeted PLAP

LGR: long bone growth rates

ERT: enzyme replacement therapy

PPi: inorganic pyrophosphate

ALPL: alkaline phosphatase gene

AAV: adeno-associated virus

BMC: bone marrow cells

PCR: polymerase chain reaction

Asp: aspartic acid

$\mathrm{WT}:$ Alp $^{{ }^{1+}}$

BV: bone volumes

BMC: bone mineral contents

BMD: bone mineral density

TMC: tissue mineral contents

TMD: tissue mineral density 
Submit or recommend next manuscript to SCIRP and we will provide best service for you:

Accepting pre-submission inquiries through Email, Facebook, LinkedIn, Twitter, etc. A wide selection of journals (inclusive of 9 subjects, more than 200 journals)

Providing 24-hour high-quality service

User-friendly online submission system

Fair and swift peer-review system

Efficient typesetting and proofreading procedure

Display of the result of downloads and visits, as well as the number of cited articles Maximum dissemination of your research work

Submit your manuscript at: http://papersubmission.scirp.org/

Or contact ojst@scirp.org 